\title{
Aqueous IR Bagendit rice leaf extract decreases reticulocyte count in lead-exposed rats
}

\author{
Budi Santosa*, Henna Ria Sunoko**, and Andri Sukeksi*
}

\begin{abstract}
\section{BACKGROUND}

Lead acetate may inhibit the enzyme aminolevulinate dehydratase (ALAD) resulting in decreased heme synthesis (and consequently in anemia) but in increased number of reticulocyte cells. IR Bagendit paddy leaf water extract has a high metallothionein protein content which acts to bind to lead. The study objective was to determine whether aqueous IR Bagendit rice leaf extract dosage variations prior to lead exposure decreases reticulocyte count in lead-exposed rats.
\end{abstract}

\section{METHODS}

The study was of randomized post test only control-group design involving a sample of 28 rats, that were randomized into 4 groups consisting of 1 control group and 3 treatment groups, daily administered with aqueous IR Bagendit rice leaf extract of respectively $0.2 ; 0.4 ; 0.8 \mathrm{mg}$ using a feeding tube up to week 13. Lead exposure was also given using a feeding tube to both control and treatment groups at a dose of $0.5 \mathrm{~g} / \mathrm{kg} \mathrm{BW} /$ day, up to week 13. The reticulocyte count was then examined using supravital brilliant cresyl blue staining. The reticulocyte count was determined per 1000 erythrocytes and then converted into a percentage. Kruskal Wallis test followed with Bonferroni test was conducted to figure out the differences between groups.

\section{RESULTS}

Mean reticulocyte count decreased significantly, starting from the control group up to the third treatment group $(15.48 \pm 3.41 ; 12.25 \pm 03.28 ; 10.45$ $\pm 1.47 ; 9.10 \pm 2.35$ average per unit $(\mathrm{p}=0.02)$. The Bonferroni test showed that the reticulocyte count was significantly decreased in the third treatment group $(\mathrm{p}=0.004)$.

\section{CONCLUSION}

Aqueous rice leaf extract significantly decreases reticulocytes in rats exposed to lead.

Keywords: IR Bagendit, reticulocytes, exposed, lead, metallothionein, rats
*Department of Medical Laboratory Technology,

Faculty of Nursing and Health

Science,

Muhammadiyah University,

Semarang

**Department of Pharmacy,

Dr Kariadi Hospital,

Diponegoro University, Semarang

\section{Correspondence:}

Dr. Budi Santosa,S.KM,M.Si.Med

Medical Laboratory Technology,

Faculty of Nursing and Health Science, Muhammadiyah University

J1 Kedungmundu Raya 18 Semarang

Mobile: +62818 05867211

Email: budisantosa@unimus.ac.id

Date of first submission, June 4, 2017

Date of final revised submission, April 16, 2018

Date of acceptance, April 18, 2018

This open access article is distributed under a Creative Commons AttributionNon Commercial-Share Alike 4.0

International License

Cite this article as: Santosa B, Sunoko HR, Sukeksi A. Aqueous IR Bagendit rice leaf extract decreases reticulocyte count in lead-exposed rats. Univ Med 2018;37: 57-64. doi: 10.18051/UnivMed.2018. v37.57-64 


\section{INTRODUCTION}

In Indonesia the use of lead is still relatively high, although it has largely been abandoned in the case of automotive fuels. The principal sources of lead intoxication are vegetables contaminated as a result of the use of phosphate fertilizers, pesticides, and herbicides. In addition, the use of batteries, paints, cosmetics, jewelry, toys, gasoline, etc., also constitutes a source of lead intoxication because they use lead as raw material. Lead exposure in humans may occur through leadcontaminated air, foods, and drinks. Those at highest risk of lead intoxication are children, pregnant women, and industrial workers. ${ }^{(1)}$ One of the symptoms of lead intoxication is anemia ${ }^{(2)}$ that is accompanied by increased reticulocyte count, decreased hematocrit concentration, and the presence of erythrocyte inclusions, i.e. basophilic stippling. ${ }^{(3,4)}$

The study conducted by Sunoko ${ }^{(5)}$ showed that the blood lead content at a concentration of $\geq 7 \mu \mathrm{g} / \mathrm{dl}$ may cause inhibition of enzyme activity for hemoglobin synthesis, leading to a subclinical effect that is marked by the occurrence of elevated concentrations of $\delta$-aminolevulinic acid $(\delta$ ALA) and protoporphyrin in children, resulting in anemia. The occurrence of anemia depends on the lead concentration that may inhibit the activities of ferrochelatase, aminolevulinic acid synthetase (ALAS), and aminolevulinic acid dehydratase (ALAD), three important enzymes associated with heme synthesis. Exposure to lead at $10 \mu \mathrm{g} / \mathrm{dl}$ may already inhibit ALAD, causing accumulation of aminolevulinic acid, so resulting in failure of heme synthesis that carries the risk of anemia. ${ }^{(6)}$ Cases of anemia are usually also accompanied by an increase in reticulocyte count. A low reticulocyte count indicates aplasia or disorders of the bone marrow. Peripheral blood smears may supply additional information in patients with anemia in each of the morphological aspects, particularly reticulocytes. ${ }^{(7)}$

The reticulocyte count constitutes an important parameter in the diagnosis of anemia from lead exposure. Reticulocytes are non- nucleated erythroid cells that may visualized with supravital staining that colors ribonucleic acid (RNA). Supravital stains that may be used are solutions of brilliant cresyl blue, new methylene blue, azure B, and acridine orange for visual methods. The reticulocyte count is an important component of the complete blood examination that is relatively accurate, simple, and practical for describing the number of erythrocytes produced by the erythropoietic system. ${ }^{(8)}$

The benefit of the reticulocyte count is for knowing the erythropoietic activity. An absolute increase in reticulocyte count marks the presence of increased erythropoietic activity. In anemia, there is also increased erythropoietic activity, accompanied by an increase in reticulocyte count, which is inversely correlated with hemoglobin concentration, with higher reticulocyte counts indicating lower hemoglobin concentrations. In lead intoxication there is anemia so that the reticulocyte count is increased. ${ }^{(9)}$ The study conducted by Hariono ${ }^{(10)}$ showed an increase in reticulocyte count since the $10^{\text {th }}$ week after oral administration of lead acetate at $0.5 \mathrm{~g} / \mathrm{kg} / \mathrm{BW} /$ day in rats for 16 weeks.

The study by Hariono ${ }^{(10)}$ also showed the occurrence of anemia accompanied by an increase in $\delta$ aminolevulinic acid dehydratase (ALAD) activity, and a decrease in body weight. In heme biosynthesis, lead intoxication depresses enzyme activities at the starting point (ALAD), at midpoint (coproporphyrinogen oxidase), and at the endpoint (ferrochelatase) of heme biosynthesis, thus leading to anemia. Approximately $90 \%$ of the lead introduced into the circulation will enter the erythrocytes, where it acts as a pro-oxidant, causing oxidative stress that results in damage to the erythrocyte membranes and shortening of the erythrocyte lifespan. ${ }^{(3,4)}$ Membrane damage and shortened erythrocyte lifespan cause a decrease in erythrocyte numbers and volume in the blood. This increases the erythropoietic activity that is marked by an increase in reticulocyte count. Lead may also cause glucose- 6 phosphate dehydrogenase (G-6PD) deficiency and inhibit pyrimidine-5'- 
nucleotidase that may cause the accumulation of ribonucleic acid (RNA). ${ }^{(3,4)}$

Preventive measures against lead intoxication need to be studied and developed so that its effects will not become more severe. To date lead intoxication is managed with chelating agents, e.g. ethyelenediamine tetra-acetic acid (EDTA) and 2,3-dimercaprol, but the use of these substances is curative, not preventive. Chelating agents are substances that act to bind toxic metal ions, so forming complex structures that are readily excreted by the body, either intracellularly or extracellularly. Dimercaprol has long been used for the treatment of lead and arsenic intoxication, but has dangerous side effects so that less toxic analogs need to be developed. ${ }^{(11)}$

These preventive measures to be developed may use vegetable substances that can bind to lead. One of these is the aqueous extract of the leaves of the IR Bagendit variety of rice (Oryza sativa $\mathrm{L}$ ). The leaves of IR Bagendit rice have the highest metallothionein protein content among vegetable substances such as corn, soybeans, and green beans. ${ }^{(12)}$ The metallothionein proteins can bind to lead in the tissues via their sulfhydryl groups. ${ }^{(13)}$ Metallothioneins can be synthesized in the liver as well as in the gastrointestinal wall through the absorption of various vegetable substances as well as micronutrients, such as zinc, and has been demonstrated to improve heme biosynthesis, hematopoiesis, epithelial degeneration and necrosis of the renal tubule, and basophilic stippling. ${ }^{(14,15)}$

The study conducted by Santosa et al. ${ }^{(16)}$ reported that zinc supplementation administered in stepwise increasing daily doses to rats (Rattus norvegicus) was able to increase metallothioneins and that the effect had a positive correlation, i.e. the higher the administered zinc dose, the higher the mean metallothionein concentration. In a subsequent study, metallothioneins were proven to be able to prevent the inhibition of heme biosynthesis, hematopoiesis, and epithelial degeneration and necrosis of the renal tubule in rats exposed to lead. ${ }^{(14,15)}$ This showed that metallothioneins are consistent metal- binding proteins in the tissues of all organisms. Regarding vegetable substances, it turns out that metallothioneins are abundantly present in the aqueous extract of IR Bagendit rice leaves. ${ }^{(12)}$ With reference to the supplementation dose and the metallothionein content of IR Bagendit rice leaves, administration of stepwise increasing doses for determining the efficacy of the doses should be considered, e.g. $10 \mathrm{mg}$ per day, $20 \mathrm{mg}$ per day and $40 \mathrm{mg}$ per day in humans. These doses can be converted to doses for the test animals, becoming $0.2 \mathrm{mg}, 0.4 \mathrm{mg}$, and $0.8 \mathrm{mg}$, respectively. ${ }^{(16)}$ In the present study the event to be observed was not anymore the increase in reticulocyte count as a result of lead exposure, as was proven in previous studies that yielded consistent results, i.e. the presence of substantial numbers of reticulocytes, but whether the aqueous extract of IR Bagendit rice leaves administered to lead-exposed rats may reduce the reticulocyte count. The objective of the present study was to determine the effect of the aqueous extract of IR Bagendit rice leaves on the reticulocyte count in rats exposed to lead.

\section{METHODS}

\section{Study design}

This study used a randomized post-test only control group design. ${ }^{(17)}$ The test animals (Rattus norvegicus) were maintained and subjected to the interventions in the Integrated Research and Testing Laboratory (LPPT), Gadjah Mada University, Yogyakarta. The study was carried out from May to August 2017.

\section{Experimental animals}

Determination of the sample size (SS) was performed with the formula: $\mathrm{SS}=(\mathrm{t}-1)(\mathrm{r}-1)$ $\geq 15$ where $t=$ number of groups and $r=$ number of test animals per group. The study used 3 intervention groups and 1 control group, so that $\mathrm{t}=4,(4-1)(\mathrm{r}-1) \geq 15-\mathrm{r} \geq 6$. The number of rats used was 6 for each group ( 3 intervention groups and 1 control group) so that the total sample size used in this study was 24 . To the number of rats 
in each group, one rat was added in reserve to anticipate the possibility of the rats dying, so that the total sample size was 28 rats (Rattus norvegicus). The selected rats were all males, aged 15 weeks and weighing 180-220 grams. The maintenance and intervention of the test animals (Rattus norvegicus) was performed in the Integrated Research and Testing Laboratory (LPPT), Gadjah Mada University, Yogyakarta. The maintenance from the selection period up to and including the intervention period lasted 100 days. In the intervention period the rats received standard pellet feed, aqueous extract of IR Bagendit rice leaves, and lead via feeding tubes of appropriate size.

\section{Aqueous extract of IR Bagendit rice leaves}

By simple random sampling, the 28 rats were divided into 4 groups i.e. 1 control group and 3 intervention groups. From the first week up to the $13^{\text {th }}$ week, the intervention groups received aqueous extract of IR Bagendit rice leaves in stepwise increasing doses, at $0.2,0.4$, and 0.8 $\mathrm{ml} /$ day, respectively, via feeding tube, whereas the control group did not receive the aqueous extract. The aqueous extract of IR Bagendit rice leaves in question was an extract prepared by infusion. The concentrations chosen were $0.2 \mathrm{ml}$, $0.4 \mathrm{ml}$, and $0.8 \mathrm{ml}$, referring to the metallothioneins contained in these volume doses. ${ }^{(12)}$

\section{Lead exposure}

Exposure to lead acetate was administered orally for 100 days, using a feeding tube, at a dose of $0.5 \mathrm{~g} / \mathrm{kg} \mathrm{BW} /$ day in all groups, both control and intervention groups. ${ }^{(10)}$

\section{Determination of the reticulocyte count}

On the last day of the $13^{\text {th }}$ week the reticulocyte count was determined in the control and intervention groups. Specimens for the reticulocyte count consisted of whole blood with EDTA anticoagulant, as part of the normal fluid composition in the vacutainer. Reticulocyte counting used blood smears with supravital Brilliant Cresyl Blue staining. The reticulocytes were counted per 1000 erythrocytes in the blood smears and the count multiplied by $100 \%$ to convert the result into a percentage (\%). The normal value of the reticulocyte count is $0-1 \%{ }^{(18)}$ Determination of the blood parameters was performed at the Health Analyst Clinical Pathology Laboratory, Department of Medical Laboratory Technology, Faculty of Nursing and Health Science, Muhammadiyah University, Semarang (UNIMUS).

\section{Data analysis}

Data analysis for determining the optimal concentration of aqueous extract of IR Bagendit rice leaves in decreasing the reticulocyte count in rats exposed to lead was conducted with the Kruskal Wallis test, followed by Bonferroni's test.

\section{Ethical clearance}

The present study obtained ethical clearance from the Ethics Commission, Faculty of Medicine, Universitas Islam Sultan Agung (UNISSULA) Semarang, under No. 209/VI/2017/Komisi Bioetik. The results of the ethical clearance were sent to the Head of the Integrated Research and Testing Laboratory (LPPT), Gadjah Mada University, Yogyakarta. and constituted approval for starting the study.

\section{RESULTS}

The reticulocytes are formed because of the accumulation of ribonucleic acid (RNA) and ribosomes in the erythrocytes as a result of inhibition of the enzyme pyrimidine-5'nucleotidase in lead exposure. In Figure 1, the control group $\mathrm{K}$ that did not receive aqueous extract of IR Bagendit rice leaves had a higher reticulocyte count compared with the intervention groups that did receive the extract, i.e. intervention groups P1 (0.2 mg), P2 (0.4 mg), and P3 (0.8 $\mathrm{mg})$.

At baseline, the weight of the test animals did not show significant differences $(\mathrm{p}=0.202)$. This indicates that the performed block 


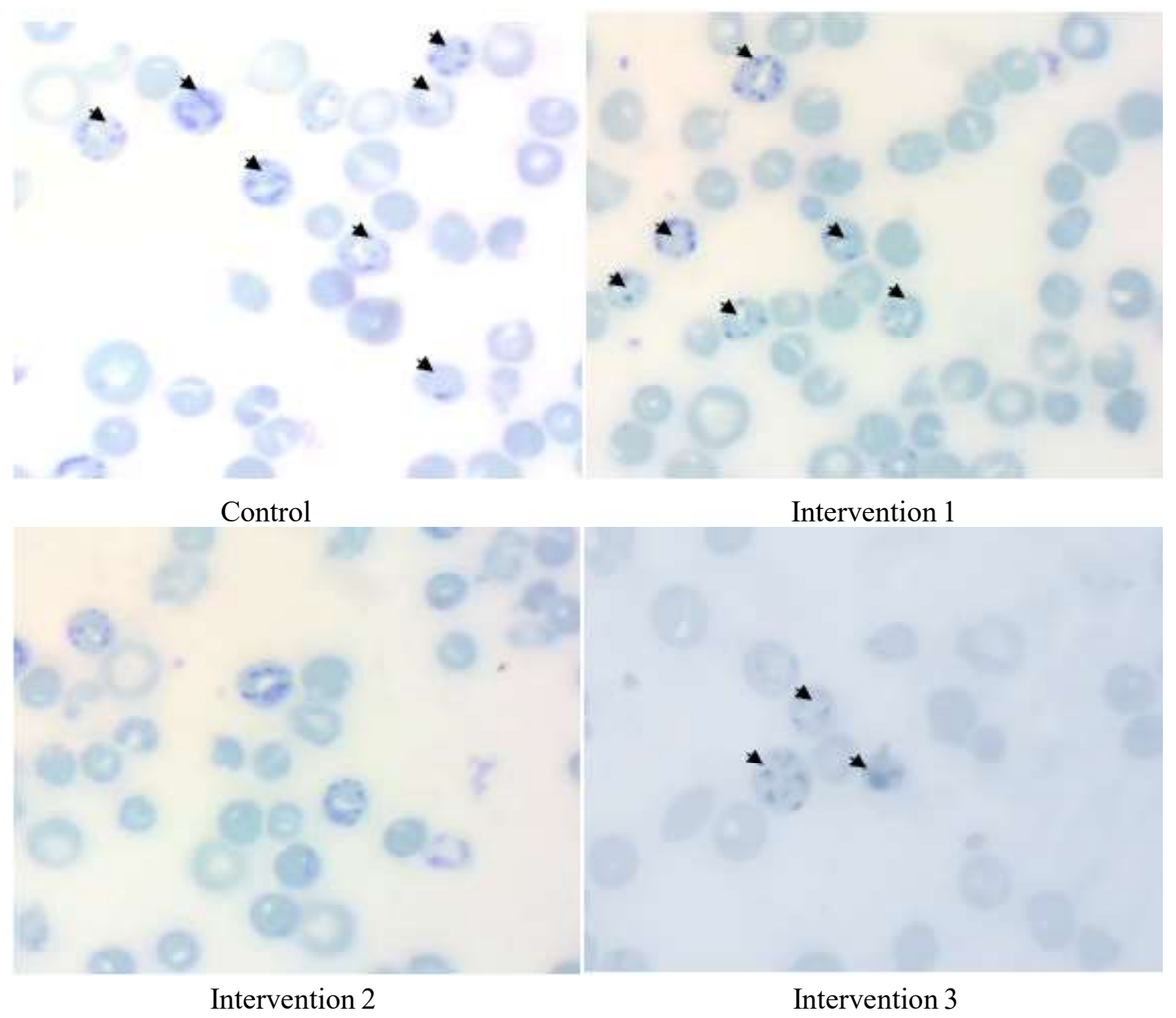

Figure 1. Reticulocyte count in control group and intervention groups 1,2, and 3 (magnification 1000x).

Arrowheads point to reticulocytes

randomization procedure was able to distribute the weights evenly among the four groups. After administration of the intervention, there was an increase in the weight of the test animals, particularly in the intervention groups $(p=0.000)$. The results of the Kruskal-Wallis test showed a significant decrease in reticulocyte count after administration of the intervention for 13 weeks, particularly in the intervention groups receiving
IR Bagendit rice leaf extract at $0.8 \mathrm{~mL} /$ day $(p=0.021)$ (Table 1).

According to the results of Bonferroni's test (Table 2), the difference in the reticulocyte count was between the control group and intervention group P2 that received IR Bagendit rice leaf extract at $0.4 \mathrm{mg}(\mathrm{p}=0.013)$ and between the control group and intervention $\mathrm{P} 3$ that received IR Bagendit rice leaf extract at $0.8 \mathrm{mg}(\mathrm{p}=0.004)$.

Table 1. Mean reticulocyte count and difference in body weight after the $13^{\text {th }}$ week, by intervention group

\begin{tabular}{|c|c|c|c|c|c|}
\hline \multirow{2}{*}{ Variable } & \multicolumn{4}{|c|}{ Intervention } & \multirow{2}{*}{ p value } \\
\hline & $K(n=7)$ & P1 $(n=7)$ & P2 $(n=7)$ & P3 $(n=7)$ & \\
\hline \multicolumn{6}{|l|}{ Base line } \\
\hline Body weight (g) & $185.71 \pm 2.39$ & $189.6 \pm 1.36$ & $188.39 \pm 1.07$ & $187.50 \pm 5.42$ & 0.202 \\
\hline \multicolumn{6}{|l|}{ After intervention } \\
\hline Body weight (g) & $211.72 \pm 4.08$ & $218.80 \pm 3.56$ & $217.70 \pm 2.01$ & $214.67 \pm 1.01$ & 0.000 \\
\hline Reticulocyte count $(\%)$ & $15.48 \pm 3.41$ & $12.25 \pm 3.28$ & $10.45 \pm 1.47$ & $9.10 \pm 2.35$ & 0.021 \\
\hline
\end{tabular}


Table 2. Bonferroni's multiple comparison test of reticulocyte count after thirteenth week, by treatment group

\begin{tabular}{lcc}
\hline & Mean difference & p value \\
\hline K P1 & 3.23 & 0.182 \\
P2 & 5.03 & 0.013 \\
P3 & 6.36 & 0.004 \\
P1 P2 & 1.79 & 0.652 \\
P3 & 3.12 & 0.263 \\
P2 P3 & 1.33 & 0.834 \\
\hline
\end{tabular}

$\mathrm{K}$ : control; P1: intervention group receiving IR Bagendit rice leaf extract at $0.2 \mathrm{~mL} /$ day; $\mathrm{P} 2$ : intervention group receiving IR Bagendit rice leaf extract at $0.4 \mathrm{~mL} /$ day; P3 : intervention group receiving IR Bagendit rice leaf extract at $0.8 \mathrm{mg} / \mathrm{mL} /$ day

\section{DISCUSSION}

In the present study there was a decrease in the mean reticulocyte count. The highest mean reticulocyte count was in the control group that did not receive IR Bagendit rice leaf extract. The lowest mean reticulocyte count was in intervention group P2 that received IR Bagendit rice leaf extract at the highest dose of $0.8 \mathrm{mg}$. Statistically there was a significant difference in reticulocyte count between the control group and the intervention groups. The higher the dose of the IR Bagendit rice leaf extract, the lower the reticulocyte count in the rats exposed to lead.

The results this study were supported by the study of Hariono ${ }^{(10)}$, in that exposure to lead at $0.5 \mathrm{~g} / \mathrm{kg} / \mathrm{BW}$ was proven to increase the reticulocyte count in the rats in the $10^{\text {th }}$ week. The reticulocytes are marked by punctate forms and bleaching of the blue color in the erythrocytes that frequently occur in cases of lead exposure. Lead inhibits pyrimidine-5'-nucleotidase and alters the function of the other nucleotides. Lead can disturb heme synthesis, so changing the concentrations of enzymes and intermediates in heme synthesis or its derivatives. Lead poisoning may cause an increased reticulocyte count in the blood. ${ }^{(19)}$ The novelty of the present study compared with previous studies lies in the fact that the reticulocyte count may have decreased because of the administration of IR Bagendit rice leaf extract in the rats exposed to lead.
Lead exposure may cause membrane damage in the erythrocytes, so shortening their lifespan and decreasing the erythrocyte count. The bone marrow as the site of erythropoiesis will compensate for the decreased numbers of erythrocytes in the circulation by increasing the erythropoietic activity, causing an increase in immature erythrocytes in the circulation. ${ }^{(4,20)}$

In this study, lead exposure without aqueous IR Bagendit rice leaf extract resulted in high mean reticulocyte count, whereas lead exposure with aqueous IR Bagendit rice leaf extract resulted in decreased mean reticulocyte count. This demonstrates that aqueous IR Bagendit rice leaf extract was able to decrease the reticulocyte count in rats exposed to lead.

The reticulocyte count is the number of non-nucleated erythrocyte with remains of RNA. The reticulocyte count is considerably affected by the erythrocyte count and hemoglobin concentration. The lower the erythrocyte count and hemoglobin concentration, the higher the erythropoietic activity that increases the reticulocyte count. In this study, increased erythropoietic activity was marked by an increased reticulocyte count in lead-exposed rats receiving the highest dose of aqueous IR Bagendit rice leaf extract (0.8). However, the reticulocyte count in lead-exposed rats that did not receive aqueous IR Bagendit rice leaf extract was lower compared with that in the rats that did receive the extract. There was a significant difference in reticulocyte count between the control group that only received lead exposure and the intervention groups that in addition to lead exposure also received aqueous IR Bagendit rice leaf extract in stepwise increasing doses, with a positive correlation of reticulocyte count with the doses. Increases in the doses of aqueous IR Bagendit rice leaf extract was followed by increased reticulocyte count in rats exposed to lead. The study conducted by Santosa and Sunoko ${ }^{(12)}$ reported that the aqueous leaf extract from several rice varieties containing the highest concentration of metallothioneins was that of the leaves of IR Bagendit rice. Metallothioneins act 
to bind lead and can improve the erythropoietic activity as a result of exposure to lead.

Most of the lead in the blood is present in the erythrocytes, where $90 \%$ is in the cytoplasm and $10 \%$ in the membrane, particularly in lipids and lipoproteins. ${ }^{(4)}$ The distribution of lead in the plasma and erythrocyte membrane is due to the presence of lead bound to cytoplasmic elements, transportation via the erythrocyte membrane, and excretion through the calcium pump. The toxic effect of lead in erythrocytes is due to destruction of the erythrocytes, accelerating the sequestration of the erythrocytes in the spleen via exposure to phosphatidylserine (PS) and then increasing erythrophagocytosis. ${ }^{(21)}$

Many investigators have reported that the principal mechanism of lead toxicity is the production of free radicals. Reactive oxygen species (ROS) react with cellular macromolecules (DNA, proteins, lipids). ${ }^{(22)}$ Erythrocytes are very susceptible to induction of oxidative stress due to high lead exposure. ${ }^{(22,23)}$

According to Murray et al..$^{(3)}$ and Luis et al. ${ }^{(4)}$, approximately $90 \%$ of the lead introduced into the circulation will enter the erythrocytes. In the erythrocyte membrane there occur chemical reactions producing potentially toxic oxygen species called pro-oxidants. Increases in the amount of pro-oxidants may cause oxidative stress. Lead may also cause deficiency of the enzyme G-6PD (glucose-6 phosphate dehydrogenase) that may inhibit erythrocyte maturation in the bone marrow. ${ }^{(3,4)}$

Gugliotta et al. (24) investigated the effect of lead on the proteins in the erythrocyte membrane. Their results showed a decreased erythrocyte count, with membrane permeability playing an important role in the decrease. An in vitro study on lead exposure of erythrocytes that was conducted by Mrugesh et al. ${ }^{(25)}$ proved that lead nitrate is a cytotoxic agent that may cause hemolysis even at extremely low concentrations.

In the experimental laboratory study conducted by Gugliotta, ${ }^{(24)}$ heparinized blood with hematocrit concentration of $3 \%$ was incubated for 1 hour at $25^{\circ} \mathrm{C}$ in a medium containing increasing concentrations of lead chloride $(0,0.3$, 0.5 and $1 \mu \mathrm{M})$. The results of the study showed an increase in erythrocyte permeability with consequent cellular damage and death, particularly at high lead concentrations, changes in morphology and membrane structure of the red blood cell, and decreased erythrocyte ATP concentrations.

The clinical implication of this study is that aqueous IR Bagendit rice leaf extract was proven to decrease the reticulocyte count in rats exposed to lead, indicating that aqueous IR Bagendit rice leaf extract decreases the impact of lead exposure, and therefore needs further study for its application in humans. One limitation of this study is that the highest administered dose is 0.8 $\mathrm{ml}$, so leaving open the question whether doses higher than $0.8 \mathrm{ml}$ can still decrease the reticulocyte count. Future developments of this study should be in the form of clinical trials on the use of aqueous rice leaf extract for the prevention of anemia in humans exposed to lead. The gene coding for the metallothionein content of the rice leaves should also be studied.

\section{CONCLUSION}

Aqueous IR Bagendit rice leaf extract at a concentration of $0.8 \mathrm{ml}$ is able to optimally decrease the reticulocyte count in rats exposed to lead.

\section{ACKNOWLEDGMENT}

The authors thank the Ministry Research and Technology, Directorate of Higher Education (Ristek Dikti) for the funding of this study through grants.

\section{CONTRIBUTORS}

BS formulated the design of the study, conducted the experiments, performed data analysis, drafted, revised and critically reviewed the manuscript. HRS contributed to data collection and analysis. AS contributed to preparation of 
reagents and material, and to data analysis. All authors read and approved the final manuscript.

\section{REFERENCES}

1. National Health \& Medical Research Council. Blood lead levels: lead exposure and health effects in Australia. National Health \& Medical Research Council 2009. Melboune: National Health \& Medical Research Council;2009.

2. Hegazy AA, Zaher MM, Abd el-hafez MA, et al. Relation between anemia and blood levels of lead, copper, zinc and iron among children. BMC 2010;3:133-8. DOI: https://doi.org/10.1186/17560500-3-133.

3. Murray RK. Porphyrin and bile pigments. In: Murray RK, Granner DK, Rodwell VW, editors. Harper's Illlustrated Biochemistry. 30 ${ }^{\text {th }}$ ed. New York: McGraw-Hill ;2015.p.279-93.

4. Luis TC, Weerkamp F, Naber BAE, et al. Wn3ta deficiency irreversibly impairs hematopoietic stem cell self-renewal and leads to defects in progenitor cell differentiation. Blood 2009;113:546-54.

5. Sunoko HR. Peran gen polimorfik $\alpha$ asam aminolevulinic acid dehidratase (ALAD) pada intoksikasi Pb. MMI 2008;43:1-10.

6. Kim HC, Jang TW, Chae HJ, et al. Evaluation and management of lead exposure. Ann Occup Environ Med 2015; 27:1-9. DOI: 10.1186/s40557015-0085-9.

7. Janus J, Hopkins J, Sarah MK. Moerschel, MD. Evaluation of anemia in children. Am Fam Physician 2010;81:1462-71.

8. Lanzkowsky P, editor. Classification and diagnosis of anemia in children. In. Lanzkowsky's Manual of pediatric hematology and oncology. $6^{\text {th }}$ ed. New York :Academic Press;2016.p.32-41

9. Kalahasthi R, Barman T. Effect of lead exposure on the status of reticulocyte count indices among workers from lead battery manufacturing plant. Toxicol Res 2016; 32 :281-7. DOI: https://doi.org/ 10.5487/TR.2016.32.4.281.

10. Hariono B. Efek pemberian plumbum (timah hitam) pada tikus putih anorganik (Rattus norvegicus). J Sain Vet 2006;24:125-33.

11. Flora SJS, Pachauri V. Chelation in metal intoxication. Int J Environ Res Public Health 2010; 7:2745-88. doi: 10.3390/ijerph7072745.

12. Santosa B, Sunoko HR. Analysis, identification, and formulation of metallothionein extracts on numerous varieties of paddy leaves. Semnas Unimus 2017;95-9.

13. Murthy S, Bali G, Sarangi SK. Effect of lead on metallothionein concentration in lead-resistant bacteria Bacillus cereus isolated from industrial effluent. African J Biotechnol 2011;10:15966-72 DOI: https://doi.org/10.5897/AJB11.1645.

14. Santosa B, Subagio WS, Suromo L, et al. Zinc supplementation improves heme biosynthesis in rats exposed to lead. Univ Med 2015;24:3-9. DOI: http://dx.doi.org/10.18051/UnivMed.2015.v34.3-9.

15. Santosa B, Subagio WS, Suromo L, et al. Zinc supplementation decreases basophilic stippling in rats exposed to lead. Univ Med 2014;33:11-8 DOI: http://dx.doi.org/10.18051/Univ Med.2014. v33.11-18.

16. Santosa B, Subagio WS, Suromo L, et al. Zinc supplementation dosage variations to metallothionein protein level of Rattus norvegicus. Int J Sci Eng 2013;5:15-7.

17. Sastroasmoro S, Ismael S. Dasar-Dasar metodologi penelitian klinis. ed ${ }^{5}$, Jakarta: CV. Sagung Seto;2014.

18. Piva E, Brugnara C, Spolaore F, et al. Clinical utility of reticulocyte parameters. Clin Lab Med 2015;35: 133-63. doi: 10.1016/j.cll.2014.10.004.

19. Jun L, Christopher JK. Reticulocyte counts in sports medicine. NZ J Med Lab Sci 2012; 66:36-8.

20. Fry MM, McGavin MD. Bone marrow, blood cell, and the lymphatic system. In: Zachary JF M, McGavin MD, editors. Pathologic basis of veterinary disease. $7^{\text {th }}$ ed. St. Louis, Missouri: Mosby;2012.p.699-702.

21. Jang WH, Lim KM, Kim K, et al. Low level of lead can induce phosphatidylserine exposure and erythrophagocytosis: a new mechanism underlying lead-associated anemia. Toxicol Sci 2011;122:177-84. DOI: http://doi.org/10.1093/ toxsci/kfr079.

22. Almeida-Lopes ACB, Peixe TS, Mesas AE, et al. Lead exposure and oxidative stress: a systematic review. Rev Environ Contam Toxicol 2016;236:193238. doi: 10.1007/978-3-319-20013-2-3.

23. Kasperczyk A, Słowińska-Łożyńska L, Dobrakowski M,et al. The effect of lead-induced oxidative stress on blood viscosity and rheological properties of erythrocytes in lead exposed humans. Clin Hemorheol Microcirc 2014; 56:187-95.

24. Gugliotta T, Luca GD, Romano P, Rigano C, Scuteri A, Romano L. Effects of lead chloride on human erythrocyte membranes and on kinetic anion sulphate and glutathione concentrations. Cel Mol Biol Lett 2012;17:586-97.

25. Mrugesh T, Dipa L, Manishika G. Effect of lead on human erythrocytes: an in vitro study. Acta Poloniae Pharmaceutica-Drug Research 2011;68: 653-6. 